\title{
Türkiye'de İntramüsküler Enjeksiyon Uygulaması ile İlgili Yapılmış Lisansüstü Hemşirelik Tezlerinin İncelenmesi
}

\author{
Tuba KARABEY1* ${ }^{*}$, Şerife KARAGÖZOĞLU²
}

${ }^{1}$ Tokat Gaziosmanpaşa Üniversitesi Sağlık Bilimleri Fakültesi, Tokat, Türkiye

${ }^{2}$ Sivas Cumhuriyet Üniversitesi, Sağlık Bilimleri Fakültesi, Hemșirelik Bölümü, Sivas, Türkiye

$\begin{array}{ccc}\text { Geliş Tarihi } & \text { Kabul Tarihi } & \text { Yayın Tarihi } \\ 03.04 .2021 & 06.10 .2021 & 31.12 .2021\end{array}$

Özet: Bu araştırma, Türkiye'de intramüsküler enjeksiyon uygulamalarını içeren lisansüstü hemşirelik tezlerinin yayın yılı, türü, amaç, yöntem ve elde edilen sonuçlarını incelemek amacıyla yapılmıştır. Araştırmada verilerin toplanması Yükseköğretim Kurulu Ulusal Tez Merkezi Veri Tabanı "Hemşirelik, İntramüsküler, İntramüsküler Enjeksiyon", anahtar kelimeleri ile taranmıștır. Tarama sonunda 1997-2020 yılları arasında Sağlık Bilimleri Enstitüsü Hemşirelik alanında konu ile ilgili yapılmış 27 tez belirlenmiştir. Veriler incelediğinde lisansüstü tezlerden 20'sinin yüksek lisans, 7'inin ise doktora düzeyinde yapıldığı görülmüştür. İntramüsküler enjeksiyon uygulaması ile ilgili ilk tezin 1997 yılında yapıldığı tespit edilmiştir. Tezler araştırma türlerine göre incelendiklerinde deneysel $(n=14)$, yarı deneysel $(n=10)$ ve tanımlayıcı $(n=3)$ türde olduğu saptanmıştır. Lisansüstü tezlerin sistematik incelemesinde, tanımlayıcı türde yapılan çalışmaların tamamının yüksek lisans tezlerinden oluştuğu, son yıllarda yapılan doktora tezlerinin daha çok randomize kontrollü olarak deneysel türde yapıldığı saptanmıştır. Yine son yıllarda yapılan tezlerin intramüsküler enjeksiyon ağrısını azaltmaya yönelik nonfarmakolojik yöntem kullanımın etkisini ortaya koyduğu belirlenmiştir. İntramüsküler enjeksiyon uygulamasını konu alan tezlerin sayıca yetersiz olduğu; konuya ilişkin akademik çalışmaların sayısının artmasının diğer araştırmalara ışık tutacağı düşünülmektedir.

Anahtar kelimeler: Hemşirelik, parenteral ilaç uygulaması, intramüsküler enjeksiyon

\section{Investigation of Nursing Postgraduate Thesis Related Conducted by Intramuscular Injection Practices in Turkey}

\begin{abstract}
In this research, publication year intramuscular injection containing the thesis of graduate nursing practice in Turkey, type, purpose, method and was conducted to examine the results obtained. Data collection in the study was scanned with the keywords "Nursing, Intramuscular, Intramuscular Injection" in the Higher Education Council National Thesis Center Database. At the end of the screening, 27 theses made on the subject in the field of Nursing at the Institute of Health Sciences between 1997-2020 were determined. When the data were examined, it was seen that 20 of the postgraduate theses were made at the master's level and 7 were at the doctoral level. It was determined that the first thesis on intramuscular injection was made in 1997. When the theses were examined according to research types, it was found that they were experimental $(n=14)$, quasi-experimental ( $n$ $=10)$ and descriptive $(n=3)$. In the systematic analysis of postgraduate theses, it was determined that all of the descriptive studies consisted of master theses and that the doctoral theses made in recent years were mostly done in the experimental type with randomized control. It has also been determined that the theses made in recent years have demonstrated the effect of using non-pharmacological methods to reduce intramuscular injection pain. The number of theses on intramuscular injection is insufficient; It is thought that increasing the number of academic studies on the subject will shed light on other studies.
\end{abstract}

Keywords: Nursing; parenteral drug administration; intramuscular injection 


\section{GİRIŞ}

İntramüsküler (IM) enjeksiyon uygulanması parenteral ilaç uygulamalarının önemli bir parçası olup, klinik uygulamada sıklıkla kullanılan yaygın bir hemşirelik işlevidir (Rodger ve King, 2000; Potter ve ark., 2017; Ağaç ve Güneș, 2011; Zhuo ve ark., 2019). IM enjeksiyon uygulaması 1940' larda antibiyotiğin keşfedilmesi ile hekimler tarafından yapılırken, 1960' ların sonlarına gelindiğinde rutin olarak hemşirelerin sorumluluğunda yapılmaya başlanmıştır (Nicoll ve Hesby 2002; Legrand ve ark., 2020). Basit bir teknik olarak düşünülmesine karşın, IM enjeksiyonlar uygun yöntemlerle yapılmadığı takdirde çok ciddi komplikasyonlara neden olabilmektedir (Small, 2004; Floyd ve Meyer, 2007; Akçimen ve ark., 2019).

İM enjeksiyonda bölge seçimi çok önemlidir. Enjeksiyon bölgesinin seçiminde; büyük kan damarlarından, sinirlerden ve kemikten uzak güvenli bir alan seçilmelidir. Enjeksiyonu doğru bölgeye uygulayabilmek için enjeksiyon yapılacak alanın iyi görülmesi gerekir. Enjeksiyon yapılacak bölgede enfeksiyon, nekroz varlığı, deri bütünlüğünde bozulma olup olmadığı kontrol edilmelidir (Karaman, 2015; Akçimen ve ark., 2019). Her bölgenin avantaj ve dezavantajları bilinmelidir. Enjeksiyon materyalinin hazırlanması, kullanılacak malzemelerin seçimi ve ağrıyı azaltıcı yöntemler enjeksiyondan önce planlanmal, enjeksiyon bölgesi belirlenerek hastaya uygun pozisyon verilmelidir (Mitchell ve Whitney, 2001; Potter ve ark., 2017).

İM enjeksiyon uygulamalarında büyük sorumluluk uygulayıcı olan hemşirelerdedir. Enjeksiyon uygulama sürecinde hasta ve çalışan güvenliğinin sağlanması, meydana gelebilecek olası komplikasyonların önlenmesi amacıyla, enjeksiyon uygulamalarının kural ve yöntemleri iyi bilinmeli, uygun teknik kullanılmalı ve uygulamalar titizlikle gerçekleştirilmelidir (Larkin ve ark., 2017; Karabey ve Karagözoğlu, 2020). Aksi taktirde hasta ve çalışan güvenliği riske atılmış olmakla beraber, yasal anlamda belirli yaptırımlarla karşı karşıya kalınabilmektedir (Berman ve ark., 2016). Zaman zaman bilgisizlik, deneyimsizlik, iletişim ve eğitim eksikliği, iş yükünün fazla olması, motivasyon eksikliği, yorgunluk, dikkat dağınıklığı gibi pek çok faktör uygulama hatalarına sebep olabilmekte, bu da hem hasta hem de hemşire üzerinde olumsuz etkilere yol açabilmektedir (Çoban ve ark., 2017; Mraz ve ark., 2018). Tüm bunların önüne geçmek için hemşire bireyi bütüncül olarak ele almalı, hekim istemindeki ilacın hasta için uygunluğunu değerlendirmeli, ilacın istenen ve istenmeyen etkilerini bilmelidir. Hemşireler aynı zamanda uygun tekniklerle enjeksiyon ağrısını azaltarak, hastanın rahatını artırmalıdır (Çöçelli ve ark., 2008; Kaya, 2012; Uslusoy ve ark., 2016).

Lisansüstü tez çalışmaları teorik bilgi ve uygulamanın bir araya geldiği bilimsel değeri yüksek ve sonuçlarının uygulamaya yansıması bakımından önemli olan çalışmalardır. Bilimsel tezlerin analiz edilmesi o konunun derinliği ve yaygınlığ hakkında bilgiler vermekte ve incelenen alanın genel görünümünü ortaya çıkarmaktadır. $\mathrm{Bu}$ bağlamda IM enjeksiyon ile ilgili yapılan lisansüstü hemşirelik tezlerinin incelenmesi ile uygulamaya dönük bilimsel bilgi üretme çabalarının ne düzeyde olduğu belirlenecektir.

Bu araştırma, Türkiye'de IM enjeksiyon uygulamalarına yönelik lisansüstü hemşirelik tezlerinin yayın yılı, türü, amaç, yöntem ve elde edilen sonuçlarının belirlemesi ile birlikte hemşirelik uygulamalarına ışık tutmayı ayrıca sağlık hizmeti sunan hemşire ve diğer sağlık personeline somut veriler sunmayı amaçlamaktadır.

Araștırma Soruları

1.Türkiye'de IM enjeksiyon uygulamalarına yönelik lisansüstü hemşirelik tezleri hangi yıllarda yayınlanmıştır?

2.Türkiye'de IM enjeksiyon uygulamalarına yönelik lisansüstü hemşirelik tezlerinin türleri nelerdir?

3.Türkiye'de IM enjeksiyon uygulamalarına yönelik lisansüstü hemşirelik tezleri

hangi amaçlarla yapılmıştır?

4.Türkiye'de IM enjeksiyon uygulamalarına yönelik lisansüstü hemşirelik tezlerinde hangi yöntemler kullanılmıștır?

5.Türkiye'de IM enjeksiyon uygulamalarına yönelik lisansüstü hemşirelik tezlerinin genel sonuçları nelerdir? 


\section{GEREÇ VE YÖNTEMLER}

$\mathrm{Bu}$ retrospektif tanımlayıcı tipte ki literatür araştırmasında 1997-2020 yılları arasında hemşirelikte Yükseköğretim Kurulu (YÖK) Ulusal Tez Merkezi Veri Tabanı'na, “Hemşirelik, İntramüsküler, İntramüsküler Enjeksiyon” anahtar kelimeleri ile tarama yapılmıștır. Araştırma için belirlenen anahtar sözcüklerin taranması sonucu 1997-2020 yılları arasında Sağlık Bilimleri Enstitüsü Hemşirelik Ana Bilim Dalında konu ile ilgili yapılmış 27 tez belirlenmiştir. Tezler yüksek lisans ve doktora tezleri olarak ayrıldıktan sonra tarih sıralamasıyla incelenmiş veriler spss paket programda analiz edilmiş, frekansları incelenmiş ve verilerin sunumunda sayı ve yüzdelik değerler kullanılmıştır.

\section{Araştırmaya dâhil edilme ölçütleri;}

$\checkmark$ Türkiye Cumhuriyeti YÖK Yayın Dokümantasyon Daire Başkanlığı tarafından 1997-2020 yılları süresince arşivlenen hemşirelik anabilim dallarında yapılmış olan tezlerin,

$\checkmark$ Başlığında “İntramüsküler", “İntramüsküler Enjeksiyon” kelimelerinin yer alması,

$\checkmark \quad$ Lisansüstü tez çalışması olması,

$\checkmark \quad$ Hemşirelik ve/veya hemşirelik ana bilim dalları tarafından yapılmış olması.

\section{BULGULAR}

Yapılan inceleme sonucunda, çalışmaya dâhil edilme kriterlerini sağlayan 27 adet lisansüstü tez incelemeye alınmıștır. Tezlerden 20'sinin yüksek lisans, 7'inin ise doktora düzeyinde yapıldığı görülmüştür (Tablo 1).

Tablo1. İncelenen Lisansüstü Tezlerin Türlerine Göre Dağılımı

\begin{tabular}{l|cc}
\hline Tez Türü & $\mathrm{n}$ & $\%$ \\
\hline Yüksek Lisans & 20 & 78.26 \\
Doktora & 7 & 21.74 \\
\hline
\end{tabular}

IM enjeksiyon uygulamasına ilişkin ilk tezin 1997 yılında yapıldı̆̆ı ve tezlerin büyük çoğunluğunu (n=5) 2017 yılına ait olduğu saptanmıştır (Tablo 2).
Tablo 2. İncelenen Lisansüstü Tezlerin Yayınlanma Yılına Göre Dağılımı

\begin{tabular}{ccc}
\hline Yayınlanma Yılı & $\mathbf{n}$ & $\mathbf{\%}$ \\
\hline 1997 & 1 & 3.70 \\
1998 & 1 & 3.70 \\
2011 & 3 & 11.11 \\
2012 & 1 & 3.70 \\
2013 & 2 & 7.40 \\
2014 & 1 & 3.70 \\
2015 & 1 & 3.70 \\
2016 & 2 & 7.41 \\
2017 & 5 & 18.52 \\
2018 & 2 & 7.41 \\
2019 & 2 & 7.41 \\
2020 & 6 & 22.22 \\
\hline
\end{tabular}

Tezler araştırma türlerine göre incelendiklerinde deneysel ( $\mathrm{n}=14)$, yarı deneysel $(\mathrm{n}=10)$ ve tanımlayıcı $(\mathrm{n}=3)$ türde olduğ belirlenmiştir (Tablo 3).

Tablo 3. İncelenen Lisansüstü Tezlerin Araştırma Türlerine Göre Dağılımı

\begin{tabular}{lll}
\hline Araştırma Türü & $\mathrm{n}$ & $\%$ \\
\hline Deneysel & 14 & 52.17 \\
Yarı Deneysel & 10 & 34.78 \\
Tanımlayıcı & 3 & 13.05 \\
\hline
\end{tabular}

Lisansüstü tezlerin sistematik incelemesinde, tanımlayıcı türde yapılan çalışmaların tamamının yüksek lisans tezlerinden oluştuğu, son yıllarda yapılan doktora tezlerinin daha çok randomize kontrollü olarak deneysel türde yapıldığı saptanmıştır. Yine son yıllarda yapılan tezlerin IM enjeksiyon uygulamasında hastaların enjeksiyona bağlı yaşanan ağrıyı azaltmaya yönelik non-farmakolojik yöntem kullanımın etkisini ortaya koyduğu belirlenmiştir (Tablo 4).

\section{TARTIȘMA}

İnceleme sonucunda IM enjeksiyon ile ilgili yapılan yüksek lisans tezlerinin doktora tezlerinden daha fazla olduğu görülmektedir. Bu sonuç, Türkiye' de doktora eğitiminin yüksek lisans eğitiminden daha geç başlaması (Velioğlu ve Oktay, 1999), hâlihazırda bulunan doktora programları ve bu programlardaki öğrenci sayısının daha az olmasıyla ilişkilendirilebilir.

Yapılan inceleme sonucunda IM enjeksiyon ile ilgili yapılan lisansüstü tezlerin büyük kısmının yüksek lisans tezlerinden oluşması ve bu tezlerin çoğunluğunun tanımlayıcı nitelikte yapılması 
ülkemizde hem eğitim hem de uygulama alanlarında temel bir hemşirelik becerisi olan IM enjeksiyon bilgi ve uygulamalarına yönelik önemli eksikliklerin olduğunu düşündürebilir. Nitekim bu konuda lisansüstü yapılan tez (Gülnar, 2012; Kılıç Arslan, 2018; Eroğlu, 2016) ve çalışmalarda (Floyd ve Meyer 2007; Walsh 2011; Tuğrul ve Denat, 2014) IM enjeksiyon uygulama bölgelerine yönelik hemşirelerde hâlâ geleneksel anlayışın hakim olduğu, kanıt düzeyi yüksek bir bilgi olmasına karşın, ventrogluteal bölgeye IM enjeksiyondan kaçındıkları ve öncelikle dorsogluteal bölgeyi tercih ettikleri görülmektedir. Çalışmamızda IM enjeksiyon ile ilgili yapılan doktora tezleri incelendiğinde ise, çalışmaların büyük kısmının yarı deneysel ve deneysel araştırmalardan oluştuğu saptanmıştır. $\mathrm{Bu}$ durum Türkiye'de yürütülen doktora programlarının nitelikli araștırmacı ve uygulayıcı yetiştirme amacına hizmet eden bir anlayışa sahip olduğunu (Ardahan ve Özsoy, 2015) ve uygulamaya dönük bilimsel bilgi üretme çabalarını gösteren önemli sonuçlar olarak değerlendirilebilir.

Tablo 4. İncelenen Lisansüstü Tezlerin Yayın Yılı Türü Amaç Yöntem ve Sonuçlarının Dağılımı

\begin{tabular}{|c|c|c|c|}
\hline \begin{tabular}{|l|} 
Tez \\
türü/yılı / \\
yazar
\end{tabular} & Amaç & Yöntem & Sonuç \\
\hline \begin{tabular}{|l|} 
Yüksel \\
Lisans, 1997, \\
Ayșe \\
Koçyiğit
\end{tabular} & $\begin{array}{|lr|}\text { İM enjeksiyonlardan önce } \\
\text { lokal anastetik etkili krem } \\
\text { EMLA uygulaması ve işlem } \\
\text { öncesi eğitim } & \text { verilerek } \\
\text { yapı-lan hazırlığın ağrıyı } \\
\text { azaltmadaki } & \text { etkinliğini } \\
\text { incelemek } & \text { amacıyla } \\
\text { yapılmıștır. } & \\
\end{array}$ & $\begin{array}{l}\text { Deneysel } \\
\mathrm{n}=48 \\
\text { Veri Toplama Araçları: } \\
\text { Kişisel Bilgi Formu, } \\
\text { Vizüel Analog Skala }\end{array}$ & $\begin{array}{|lrr|}\text { Araştırmanın } & \text { sonucunda } & \text { krem } \\
\text { EMLA grubu ve eğitim } & \text { grubu } \\
\text { çocukların } & \text { ağrı } & \text { puan } \\
\text { ortalamaları } & \text { arasında bir fark } \\
\text { bulunmamıştır. }\end{array}$ \\
\hline \begin{tabular}{|l|} 
Yüksel \\
Lisans, 1998, \\
Şerife \\
Cihangir \\
Köktepe \\
\end{tabular} & $\begin{array}{|lr|}\text { İM } & \text { enjeksiyona bağlı } \\
\text { ağrının } & \text { azaltılmasında } \\
\text { lokal buz } & \text { uygulamasının } \\
\text { etkinliğini } & \text { incelemek } \\
\text { amacıyla yapılmıștır. }\end{array}$ & $\begin{array}{l}\text { Yarı Deneysel } \\
\mathrm{n}=46 \\
\text { Veri Toplama Araçları: Kişisel Bilgi } \\
\text { Formu, } \\
\text { Vizüel Analog Skala }\end{array}$ & $\begin{array}{|lcc|}\text { Sonuç } & \text { olarak } & \text { lokal buz } \\
\text { uygulamasının İM } & \text { enjeksiyona } \\
\text { bağlı ağrıyı } & \text { azaltmadığı } \\
\text { saptanmıștır. } & \end{array}$ \\
\hline \begin{tabular}{|l|} 
Yüksek \\
Lisans, 2011, \\
Derya Uzelli
\end{tabular} & $\mid \begin{array}{lrr}0-4 & \text { haftalık } & \text { term ve } \\
\text { preterm yenidoğanlara IM } \\
\text { enjeksiyon } & \text { öncesinde } \\
\text { uygulanan } & \text { sukroz } \\
\text { solüsyonunun ağrı üzerine } \\
\text { etkisini } & \text { incelemek } \\
\text { amacıyla yapılmıştır. }\end{array}$ & $\begin{array}{l}\text { Deneysel } \\
\mathrm{n}=68 \\
\text { Veri Toplama Araçları: } \\
\text { Yenidoğan Tanıtım Formu, } \\
\text { Yenidoğan Ağrı Tanılama Ölçeği }\end{array}$ & $\begin{array}{l}\text { İM enjeksiyonda yeni doğana } \\
\text { işlem öncesinde uygulanan } \\
\text { sukroz solüsyonunun ağrıyı } \\
\text { gidermede etkili bir yöntem } \\
\text { olduğu saptanmıştır. }\end{array}$ \\
\hline \begin{tabular}{|l|} 
Yüksek \\
Lisans, 2011, \\
Dilek Kara
\end{tabular} & $\begin{array}{l}\text { İM enjeksiyon uygulaması } \\
\text { sırasında ekstremitelerin } \\
\text { internal rotasyonunun ve } \\
\text { "Z yolu tekniğinin” ağrı } \\
\text { üzerine etkisini incelemek } \\
\text { amacıyla yapılmıștır. }\end{array}$ & $\begin{array}{l}\text { Yarı Deneysel } \\
\text { n=75 } \\
\text { Veri Toplama Araçları: } \\
\text { Hasta Tanıtım Formu, } \\
\text { Vizüel Analog Skala }\end{array}$ & $\begin{array}{|lrr|}\text { Ekstremitelerin } & \text { internal } \\
\text { rotasyonu ve "Z yolu tekniği" } \\
\text { İM enjeksiyon uygulamaları } \\
\text { sırasında } \quad \text { oluşan } & \text { ağrıyı } \\
\text { azaltmada } & \text { etkili } & \text { olduğu } \\
\text { saptanmıștır. } & & \\
\end{array}$ \\
\hline \begin{tabular}{|l|} 
Yüksek \\
Lisans, 2011, \\
Derya \\
Yavure
\end{tabular} & \begin{tabular}{|lr} 
Bu çalışmanın & amacı, İM \\
enjeksiyon & öncesi \\
enjeksiyon & bölgesine \\
manüel & basınç \\
uygulanmasının & \\
enjeksiyon ağrısını azaltıp \\
azaltmadığını \\
araştırmaktır.
\end{tabular} & $\begin{array}{l}\text { Yarı Deneysel } \\
\text { n=51 } \\
\text { Veri Toplama Araçları: } \\
\text { Kişisel Bilgi Formu, } \\
\text { Vizüel Analog Skala }\end{array}$ & $\begin{array}{|lr|}\text { Enjeksiyon bölgesine manüel } \\
\text { basınç uygulamanın enjeksiyon } \\
\text { ağrısınır } \\
\text { saptanmıştır. }\end{array}$ \\
\hline \begin{tabular}{|l|} 
Yüksek \\
Lisans, 2012, \\
Emel Gülnar
\end{tabular} & 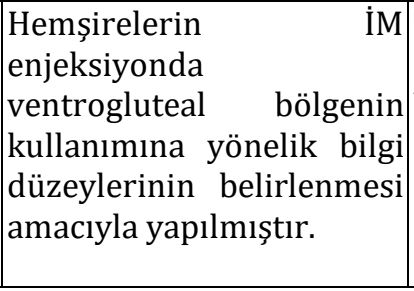 & $\begin{array}{l}\text { Tanımlayıcı } \\
\text { n=283 } \\
\text { Veri Toplama Araçları: İM } \\
\text { Enjeksiyonda Ventrogluteal Bölgenin } \\
\text { Kullanımına Yönelik Bilgi Düzeylerinin } \\
\text { Belirlenmesi Formu }\end{array}$ & \begin{tabular}{|l} 
Hemşirelerin ventrogluteal \\
bölgeyi belirleme ve kullanma, \\
İM enjeksiyon uygulaması için \\
ilk tercih edilecek bölgenin \\
ventrogluteal bölge olduğunu \\
ve dorsogluteal bölgenin tercih \\
edilmediğini bilme durumları
\end{tabular} \\
\hline
\end{tabular}




\begin{tabular}{|c|c|c|c|}
\hline & & & $\begin{array}{|lrr|}\text { ile bilgi puan } & \text { ortalamaları } \\
\text { arasındaki } & \text { farkın } & \text { istatistiksel } \\
\text { olarak } & \text { anlamlı } & \text { olduğu } \\
\text { saptanmıştır. } & \\
\end{array}$ \\
\hline $\begin{array}{l}\text { Yüksek } \\
\text { Lisans, 2013, } \\
\text { Melek Şahin }\end{array}$ & $\begin{array}{|lrr|}\text { İM enjeksiyon uygulaması } \\
\text { öncesinde ve } & \text { sırasında } \\
\text { Buzzy@ nin } & \text { ağrı } & \text { ve } \\
\text { enjeksiyon } & & \\
\text { memnuniyetine } & \text { etkisini } \\
\text { incelemek } & \text { amacıyla } \\
\text { yapılmıștır. } & & \\
\end{array}$ & $\begin{array}{l}\text { Deneysel } \\
\text { n=64 } \\
\text { Veri Toplama Araçları: } \\
\text { Hasta Bilgi Formu, } \\
\text { Vizüel Analog Skala, Enjeksiyon } \\
\text { Memnuniyet Ölçeği }\end{array}$ & $\begin{array}{|lrr|}\text { Buzzy® } & \text { aygıtının } & \text { enjeksiyon } \\
\text { ağrısını } & \text { azaltmada } & \text { ve } \\
\text { enjeksiyon } & & \text { sonrası } \\
\text { memnuniyeti } & \text { arttırmada etkili } \\
\text { bir } & \text { yöntem } & \text { olduğu } \\
\text { saptanmıştır } & \end{array}$ \\
\hline $\begin{array}{l}\text { Yüksek } \\
\text { Lisans, 2013, } \\
\text { Yonca } \\
\text { Kemaloğlu }\end{array}$ & $\begin{array}{l}\text { Araştırma } \\
\text { enjeksiyonlara bağlı ağrı, } \\
\text { kanama ve hematom riski } \\
\text { açısından dorsogluteal ve } \\
\text { ventrogluteal bölgelerin } \\
\text { karşılaştırılması amacıyla } \\
\text { yapılmıștır. }\end{array}$ & $\begin{array}{l}\text { Yarı Deneysel } \\
\text { n=100 } \\
\text { Veri Toplama Araçları: } \\
\text { Hasta Tanılama Formu, } \\
\text { Vizüel Analog Skala, } \\
\text { Opsite- Flexigrid Ölçüm Aracı }\end{array}$ & $\begin{array}{l}\text { Ventrogluteal bölgenin İM } \\
\text { enjeksiyon uygulamalarında } \\
\text { kullanılmasının daha uygun } \\
\text { olacağı sonucuna varılmıştır. }\end{array}$ \\
\hline $\begin{array}{l}\text { Yüksek } \\
\text { Lisans, 2014, } \\
\text { Nuray Caner }\end{array}$ & $\begin{array}{l}\text { Hemşirelerin parenteral } \\
\text { ilaç uygulamalarının } \\
\text { değerlendirilmesi } \\
\text { amacıyla yapılmıştır. }\end{array}$ & $\begin{array}{l}\text { Tanımlayıcı } \\
\mathrm{n}=34 \\
\text { Veri Toplama Araçları: } \\
\text { Kişisel Bilgi Formu, } \\
\text { IM uygulama gözlem formu }\end{array}$ & 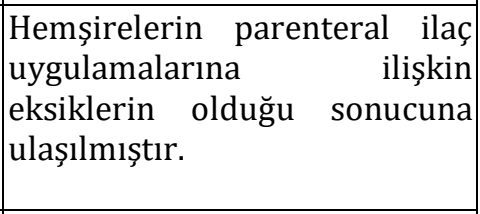 \\
\hline $\begin{array}{l}\text { Yüksek } \\
\text { Lisans, 2015, } \\
\text { Elif Kant }\end{array}$ & 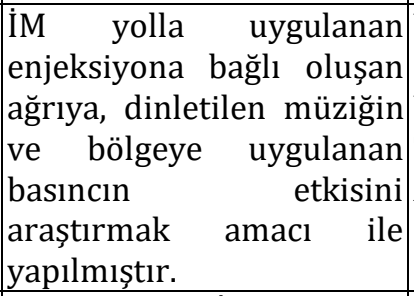 & $\begin{array}{l}\text { Yarı Deneysel } \\
\text { n=78 } \\
\text { Veri Toplama Araçları: } \\
\text { Tanıtıcı Özellikler Formu, } \\
\text { Analog Skala }\end{array}$ & $\begin{array}{lr}\text { İM enjeksiyona bağlı ağrıyı } \\
\text { azaltmada müzik } & \text { dinlemenin } \\
\text { etkili olduğu, r standart } \\
\text { enjeksiyon uygulaması ile } \\
\text { basınç uygulama yönteminin } \\
\text { etkisinin } & \text { olmadığ } \\
\text { bulunmuștur. } & \\
\end{array}$ \\
\hline $\begin{array}{l}\text { Doktora, } \\
\text { 2016, Birsen } \\
\text { Bilgen Sivri }\end{array}$ & 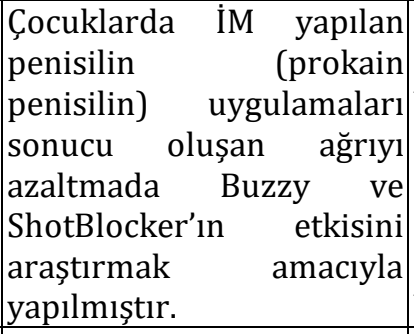 & $\begin{array}{l}\text { Deneysel } \\
\text { n=150 } \\
\text { Veri Toplama Araçları: } \\
\text { Kişisel Bilgi Formu, } \\
\text { Çocuklar İçin Durumluk } \\
\text { Envanteri, } \\
\text { Faces Pain Scale, } \\
\text { Vizüel Analog Skala }\end{array}$ & $\begin{array}{llrr}\text { Buzzy } & \text { grubundaki } & \text { çocukların } \\
\text { hem } & \text { ShotBlocker } & \text { hem } & \text { de } \\
\text { kontrol } & \text { grubundaki } & \text { çocuklara } \\
\text { oranla } & \text { istatistiksel } & \text { olarak } \\
\text { anlamlı } & \text { düzeyde düşük } & \text { ağrı } \\
\text { yaşadığı } & \text { saptanmıştır. }\end{array}$ \\
\hline $\begin{array}{l}\text { Yüksek } \\
\text { Lisans, 2016, } \\
\text { Sinem } \\
\text { Eroğlu }\end{array}$ & \begin{tabular}{|lrr} 
Ventrogluteal & alana intra- \\
müsküler & enjeksiyon \\
uygulamasına & yönelik \\
hemşirelere & ve & ebelere \\
verilen & eğitimde & Nöro \\
Linguistik & Programlama \\
(NLP) & tekniklerinin \\
etkisini & belirlemek \\
amacıyla yapılmiştır. \\
\end{tabular} & $\begin{array}{l}\text { Deneysel } \\
\text { n=90 } \\
\text { Veri Toplama Araçları: Hemşire ve Ebe } \\
\text { Tanıtım Formu, } \\
\text { Hemşirelerin } \\
\text { İntramüsküler ve } \\
\text { Uygulamasına İlişkin Görüșleri, } \\
\text { Ventrogluteal Bölgeye İlişkin Bilgi } \\
\text { Formu }\end{array}$ & $\begin{array}{|lr|}\text { Araştırma } & \text { bulguları } \\
\text { doğrultusunda, } & \text { verilen } \\
\text { eğitimde NLP tekniğinin etkili } \\
\text { olmadığı belirtilmiştir. }\end{array}$ \\
\hline $\begin{array}{l}\text { Yüksek } \\
\text { Lisans, 2017, } \\
\text { Ahmet Erol }\end{array}$ & $\begin{array}{|lr|}\text { Hemşirelik } & \text { öğrencilerine } \\
\text { İM } & \text { enjeksiyon } \\
\text { uygulamasına } & \text { ilişkin } \\
\text { uygulanan web } & \text { destekli } \\
\text { öğretimin, öğrencilerin İM } \\
\text { enjeksiyonu } \\
\text { öğrenmelerine } & \text { etkisini } \\
\text { incelemek } & \text { amacıyla } \\
\text { yapılmıştır. } & \\
\end{array}$ & $\begin{array}{l}\text { Yarı-Deneysel } \\
\text { n=66 } \\
\text { Veri Toplama Araçları: } \\
\text { Birey Tanıtım Formu, } \\
\text { İ Enjeksiyon Bilgi Formu, İM } \\
\text { Enjeksiyon Uygulama Kontrol Listesi, } \\
\text { Vizüel Analog Skala, } \\
\text { Web Destekli Eğitim Değerlendirme } \\
\text { Formu }\end{array}$ & \begin{tabular}{|lrrr} 
Klasik sınıf & içi & eğitim & ve \\
demonstrasyon & uygulamasına \\
ek olarak & öğrencilerin & eğitim \\
videoları & kullanılarak & web \\
yoluyla & \multicolumn{2}{c}{ desteklenmesi, } \\
öğrencilerin & İM & enjeksiyon \\
uygulama & & becerisini \\
artırmıştır. & &
\end{tabular} \\
\hline $\begin{array}{l}\text { Yüksek } \\
\text { Lisans, 2017, } \\
\text { Kübra Yiğit }\end{array}$ & $\mid \begin{array}{lr}\text { Araştırma } & \text { İM } \\
\text { enjeksiyonda } & \\
\text { ventrogluteal } & \text { bölgenin }\end{array}$ & $\begin{array}{l}\text { Yarı Deneysel } \\
n=30 \\
\text { Veri Toplama }\end{array}$ & $\begin{array}{l}\text { Hemşirelerin eğitim sonrası } \\
\text { bilgi düzeyleri eğitim öncesine } \\
\text { göre daha yüksek bulunmuştur. }\end{array}$ \\
\hline Gökbel & \begin{tabular}{|r} 
kullanımına ilişkin verilen \\
planlı
\end{tabular} & Tanılama Formu, & Eğitim \\
\hline
\end{tabular}




\begin{tabular}{|c|c|c|c|}
\hline & $\begin{array}{l}\text { hemşirelerin bilgi ve } \\
\text { becerileri üzerine etkisini } \\
\text { incelemeyi amaçlamıștır }\end{array}$ & $\begin{array}{l}\text { Ventroglutel Bölgeye İlişkin Bilgi } \\
\text { i Önermelerini İçeren Soru Formu, } \\
\text { Ventrogluteal Bölgeye İntramüsküler } \\
\text { Enjeksiyon Uygulama Sıklı̆̆ ve } \\
\text { Hemşirelerin Hasta Memnuniyetine } \\
\text { Yönelik Algılarını İçeren Form }\end{array}$ & $\begin{array}{l}\text { ventrogluteal bölgeye İM } \\
\text { enjeksiyon sayısını artırmıştır. }\end{array}$ \\
\hline \begin{tabular}{|l} 
Doktora, \\
2017, \\
Ela Yılmaz \\
Coşkun
\end{tabular} & $\begin{array}{|lr|}\text { Çalışma İM ilaç uygulama } \\
\text { becerisinin öğretiminde } \\
\text { bilgisayar destekli } \text { (BDS) } \\
\text { ve hibrid simülasyon (HS) } \\
\text { kullanımının öğrencilerin } \\
\text { kaygı düzeyine etkisini } \\
\text { belirlemek r amacıyla } \\
\text { yapılmıştır. }\end{array}$ & $\begin{array}{l}\text { Yarı Deneysel } \\
\text { n=81 } \\
\text { Veri Toplama Araçları: } \\
\text { Yapılandırılmış Öğrenci Bilgi Formu, } \\
\text { Durumluk-Sürekli Kaygı Envanteri, } \\
\text { i IM İlaç Uygulama Becerisi Kontrol } \\
\text { Listesi, } \\
\text { Öğrencinin Simülasyon Sonrası } \\
\text { Değerlendirme Anketi }\end{array}$ & $\begin{array}{l}\text { Çalışma sonucunda BDS } \\
\text { grubundaki ögrencilerin İM ilaç } \\
\text { uygulama becerisinde daha az } \\
\text { düzeyde kaygı yaşadığı } \\
\text { saptanmıștır. }\end{array}$ \\
\hline \begin{tabular}{|l} 
Doktora, \\
2017, Derya \\
Emre Yavuz
\end{tabular} & 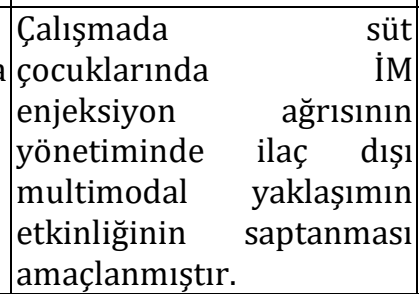 & \begin{tabular}{|l} 
Deneysel \\
n=123 \\
Veri Toplama Araçları: \\
Bilgi Formu, \\
FLACC Ağrı Tanılama Skalası, \\
Yenidoğan Ağrı Skalası
\end{tabular} & $\begin{array}{l}\text { Süt çocuklarının İM enjeksiyon } \\
\text { ağrısını azaltmak için ilaç dışı } \\
\text { multimodal yaklaşım etkili } \\
\text { bulunmuştur. }\end{array}$ \\
\hline $\begin{array}{l}\text { Yükse } \\
\text { Lisans } \\
\text { Tuğba }\end{array}$ & $\begin{array}{|lr|}\text { Araştırma İM } & \text { penisilin } \\
\text { enjeksiyonu } & \text { öncesi } \\
\text { enjeksiyon bölgesine buz } \\
\text { uygulamasının } & \text { enjeksiyon } \\
\text { ağrısı üzerine } & \text { etkisini } \\
\text { incelemek } & \text { amacıyla } \\
\text { yapılmıștır. } & \end{array}$ & \begin{tabular}{l|l} 
Deneysel \\
i $=100$ \\
Veri Toplama Araçları: \\
Tanımlayıcı bilgi formu, \\
i Vizüel Analog Skala, \\
Wong Baker Yüz Skalası
\end{tabular} & $\begin{array}{l}\text { İM penisilin enjeksiyonu öncesi } \\
\text { enjeksiyon bölgesine buz } \\
\text { uygulamasının } r \text { enjeksiyon } \\
\text { ağrısı üzerinde istatistiksel } \\
\text { olarak anlamlı bir etkisinin } \\
\text { olmadığı sonucuna ulaşılmıştır. }\end{array}$ \\
\hline $\begin{array}{l}\text { Doktora, } \\
\text { 2018, Betül } \\
\text { Kılıç Arslan }\end{array}$ & $\begin{array}{l}\text { Çalışma } \text { hemşirelerin } \\
\text { ventrogluteal } \\
\text { ilaç bölgeye İMgulama becerisinin } \\
\text { geliștirilmesinder Hibrit } \\
\text { Simülasyon Yönteminin } \\
\text { etkinliğinin } \\
\text { değerlendirilmesi } \\
\text { amacıyla yapılmıştır. }\end{array}$ & $\begin{array}{l}\text { Deneysel } \\
\text { n=117 } \\
\text { Veri Toplama Araçları: } \\
\text { Tanıtı̈ı Özellikler Formu, VG Bölgeye } \\
\text { İM Enjeksiyon Uygulaması Bilgi } \\
\text { Değerlendirme Formu, } \\
\text { Değişim Aşaması Değerlendirme Soru } \\
\text { Formu, Öğrenmede Öğrenci } \\
\text { Memnuniyeti ve Özgüven Ölçeği, } \\
\text { Ventrogluteal Bölgeye İntramüsküler } \\
\text { Enjeksiyon Uygulama Beceri Gözlem } \\
\text { Formu, } \\
\text { Eğitim Sonrası Değerlendirme Soru } \\
\text { Formu }\end{array}$ & $\begin{array}{l}\text { Hibrit Simülasyon yöntemi ile } \\
\text { eğitim alan hemşirelerin beceri } \\
\text { puan ortalamalarının anlamlı } \\
\text { düzeyde yüksek olduğu tespit } \\
\text { i edilmiştir. }\end{array}$ \\
\hline $\begin{array}{l}\text { Lisans, } 201 \\
\text { Emine } \\
\text { Apaydin }\end{array}$ & $\begin{array}{|lr|}\text { Araştırma ventrogluteal ve } \\
\text { dorsogluteal } & \text { bölgeye } \\
\text { uygulanan } & \text { IM } \\
\text { enjeksiyonları } & \text { kanama, } \\
\text { ağrı ve hematom açısından } \\
\text { karşllaştırmak } & \text { amacıyla } \\
\text { planlanmıştır. } & \end{array}$ & $\begin{array}{l}\text { Yarı Deneysel } \\
n=102 \\
\text { Veri Toplama Araçları: } \\
\text { Hasta Tanılama Formu, } \\
\text { Vizüel Analog Skala, } \\
\text { Opsite-Flexigrid Ölçüm Aracı, } \\
\text { Hematom Alanı Gruplandırması, } \\
\text { Hasta İzlem Formu }\end{array}$ & $\begin{array}{lr}\text { Ventrogluteal } & \text { bölgeyє } \\
\text { uygulanan } & \text { enjeksiyonlardc } \\
\text { ağrı, kanama } & \text { ve hematom } \\
\text { oluşumunun } & \text { dorsoglutea } \\
\text { bölgeye } & \text { uygulanar } \\
\text { enjeksiyonlardan daha az } & \text { görüldüğü saptanmıstır. }\end{array}$ \\
\hline $\begin{array}{l}\text { Yüksek } \\
\text { Lisans, 2019, } \\
\text { Sinem Özer } \\
\text { Demir }\end{array}$ & 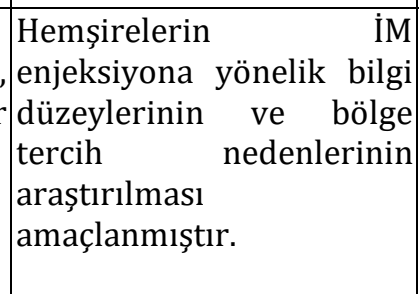 & $\begin{array}{l}\text { Tanımlayıcı } \\
\text { n=233 } \\
\text { Veri Toplama Araçları: } \\
\text { Hemşirelerin İM enjeksiyona yönelik } \\
\text { bilgi düzeylerinin ve bölge tercih } \\
\text { nedenlerinin araştırılmasına yönelik } \\
\text { veri toplama formu }\end{array}$ & $\begin{array}{l}\text { Hemşirelerin bilgi düzeyi ve } \\
\text { bölge seçimleri toplam doğru } \\
\text { cevap puan ortalaması istendik } \\
\text { düzeyde bulunmamıştır. }\end{array}$ \\
\hline $\begin{array}{l}\text { Yüksek } \\
\text { Lisans, } 201\end{array}$ & $\begin{array}{l}\text { Araştırma intramüsküler } \\
\text { enjeksiyonda ShotBlocker } \\
\text { kullanımının ağrıșiddetine }\end{array}$ & \begin{tabular}{|l|l|} 
& Deneysel \\
$n=176$ \\
Veri Topl
\end{tabular} & $\begin{array}{l}\text { ShotBlocker kullanımını } \\
\text { bireylerin enjeksiyona bağ }\end{array}$ \\
\hline
\end{tabular}




\begin{tabular}{|c|c|c|c|}
\hline  & $\begin{array}{l}\text { etkisinin belirlenmesi } \\
\text { amacıyla yapılmıștır. }\end{array}$ & $\begin{array}{l}\text { Anket formu, } \\
\text { Vizüel Analog Skala }\end{array}$ & $\begin{array}{l}\text { yaşadıkları ağrıyı azaltmadığı } \\
\text { sonucuna varılmıștır. }\end{array}$ \\
\hline \begin{tabular}{|l|} 
Doktora, \\
2020, Leyla \\
Baran
\end{tabular} & \begin{tabular}{|lr} 
Ventrogluteal & bölgeden \\
uygulanan & IM \\
enjeksiyonda & aspirasyon \\
uygulamasının & gerekliliği \\
ve ağrı üzerindeki etkisini \\
incelemek & amacıyla \\
yapılmıştır. &
\end{tabular} & $\begin{array}{l}\text { Deneysel } \\
\text { n=834 } \\
\text { Veri Toplama Araçları: } \\
\text { Birey Tanıtıcı Bilgi Formu, } \\
\text { Vizüel Analog Skala }\end{array}$ & $\begin{array}{l}\text { Araştırmanın sonucunda } \\
\text { aspirasyon süresinin ağrı } \\
\text { üzerinde etkili olduğu ve doğru } \\
\text { bir bölge tespiti ile } \\
\text { ventrogluteal bölgeden yapılan } \\
\text { İM enjeksiyonlarda aspirasyon } \\
\text { uygulamasına gerek olmadığı } \\
\text { sonucuna ulașılmıştır. }\end{array}$ \\
\hline \begin{tabular}{|l|} 
Yüksek \\
Lisans, 2020, \\
Seda Dere \\
İșseven
\end{tabular} & 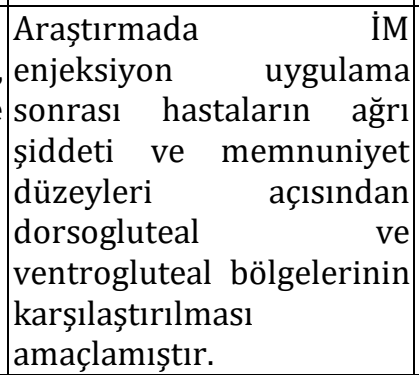 & $\begin{array}{l}\text { Yarı Deneysel n=60 } \\
\text { Veri Toplama Araçları: } \\
\text { Hasta Tanılama Formu, } \\
\text { Enjeksiyon Uygulamalarına } \\
\text { Form }\end{array}$ &  \\
\hline \begin{tabular}{|l|} 
Doktora, \\
2020, Tuba \\
Karabey
\end{tabular} & $\begin{array}{lr}\text { İM } & \text { enjeksiyon } \\
\text { uygulamasında, standart } \\
\text { enjeksiyon uygulaması, } \\
\text { ekstremitelerin } \text { internal } \\
\text { rotasyonu, lokal soğuk } \\
\text { uygulama ve ShotBlocker } \\
\text { kullanımının enjeksiyon } \\
\text { ağrısı ve konfor düzeyi } \\
\text { üzerine olan etkilerinin } \\
\text { karşılaștırılması amacıyla } \\
\text { yapılmıștır. }\end{array}$ & $\begin{array}{l}\text { Deneysel } \\
\text { n=215 } \\
\text { Veri Toplama Araçları: } \\
\text { Kişisel Bilgi Formu, } \\
\text { Vizüel Analog Skala, } \\
\text { Konfor Skalası } \\
\\
\end{array}$ & $\begin{array}{l}\text { ShotBlocker uygulamasının İM } \\
\text { enjeksiyon ağrısını azaltmada } \\
\text { enjeksiyon } \quad \text { uygulama } \\
\text { protokolü doğrultusunda } \\
\text { uygulanan standart uygulama, } \\
\text { internal rotasyon uygulaması } \\
\text { ve lokal soğuk uygulamaya } \\
\text { göre daha etkili bir yöntem } \\
\text { olduğu, bununla birlikte } \\
\text { internal rotasyon uygulaması } \\
\text { ve lokal soğuk uygulamanin da } \\
\text { İM enjeksiyon ağrısını standart } \\
\text { yönteme göre önemli düzeyde } \\
\text { azalttı̆ı ve konfor düzeyini ise } \\
\text { önemli ölçüde artırdığ } \\
\text { saptanmıștır. }\end{array}$ \\
\hline \begin{tabular}{|l|} 
Yüksek \\
Lisans, 2020, \\
SSeymanur \\
Çelik
\end{tabular} &  & \begin{tabular}{|l|} 
Yarı Deneysel \\
n=60 \\
Veri Toplama Araçları: \\
Hasta Tanıtım Formu, \\
Vizüel Analog Skala \\
\end{tabular} & \begin{tabular}{llr} 
Araştırma & \multicolumn{2}{r}{ sonucunda } \\
enjeksiyon & oncesi & manuel \\
basınç & uygulamanın & İM \\
penisilin & enjeksiyonu & ağrısını \\
azalttı̆̆ & belirlenmiştir.
\end{tabular} \\
\hline \begin{tabular}{|l|} 
Yüksek \\
Lisans, 2020, \\
Rümeysa \\
Dişçi
\end{tabular} & $\begin{array}{|lr|}\text { Çalışmanın } & \text { amacı } \\
\text { hemşirelere ventrogluteal } \\
\text { bölgeye IM } & \text { enjeksiyon } \\
\text { uygulamasına } & \text { yönelik } \\
\text { verilen kanıta } & \text { dayalı } \\
\text { eğitiminin } & \text { hemşirelerin } \\
\text { bilgi ve beceri düzeyine } \\
\text { etkisini incelemektir }\end{array}$ & \begin{tabular}{|l} 
Yarı Deneysel \\
n=54 \\
Veri Toplama Araçları: \\
Hemşirelerin Tanıtıcı Özellikleri \\
Formu, \\
Hemşirelerin Ventrogluteal Bölge İM \\
Enjeksiyon Uygulamasına Ilişkin \\
Bilgilerini Değerlendirme Formu, \\
Hemşirelerin Ventrogluteal Bölge İM \\
Enjeksiyon Becerisini Değerlendirme \\
Formu, \\
Hemşirelerin Ventrogluteal Enjeksiyon \\
Uygulama Yeterlilik Algısı Formu, \\
Hemşirelerin Kanıta Dayalı \\
Ventrogluteal Bölge IM Enjeksiyon \\
Eğitimini Değerlendirme Formu
\end{tabular} & $\begin{array}{l}\text { Yapilan araştırma sonucuna } \\
\text { göre hemşirelere verilen kanıta } \\
\text { dayalı İM enjeksiyon eğitiminin } \\
\text { i hemşirelerin bilgi ve becerileri } \\
\text { üzerinde etkili olduğu } \\
\text { sonucuna ulaşıldı. }\end{array}$ \\
\hline
\end{tabular}




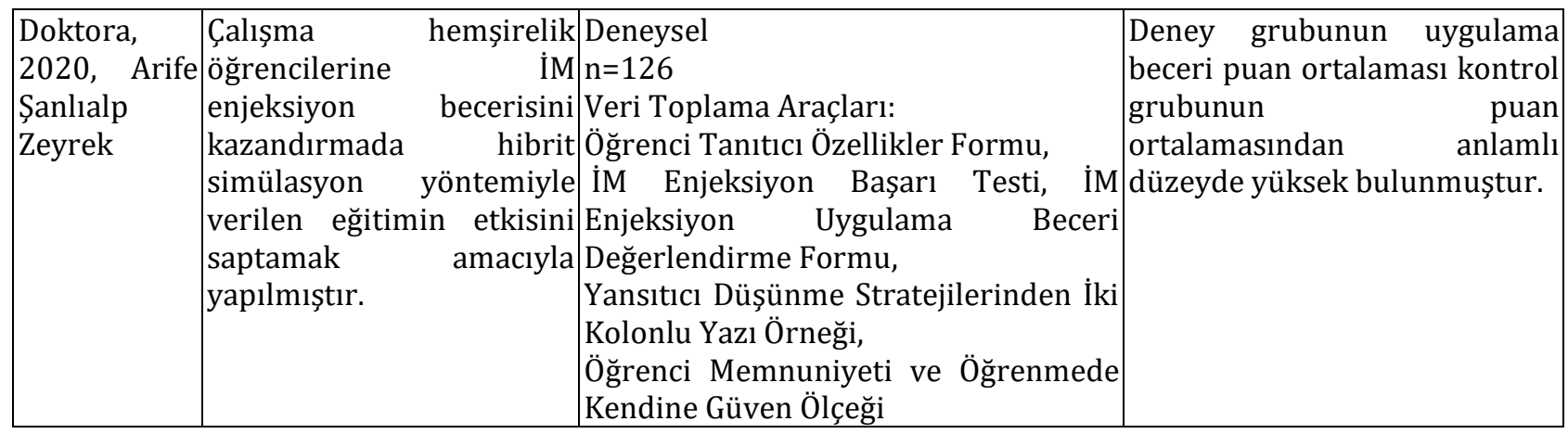

IM enjeksiyona bağlı oluşan ağrının azaltılmasında iyi bir enjeksiyon tekniği hastalar için ağrısız bir deneyim sağlayabilir (Rodger ve King, 2000; Akcimen ve ark., 2019). Bu kapsamda IM enjeksiyonuna bağlı ağrının azaltılması ve hasta konforunun artırılmasında çeşitli non-farmakolojik yöntemler kullanılmaktadır (Hunt, 2008; Demir, 2011). Yaptığımız çalışmada incelediğimiz lisansüstü tezler kapsamında, IM enjeksiyonuna bağlı ağrının azaltılması amacı ile lokal buz uygulaması, EMLA krem uygulaması, sukroz solüsyonu, manuel basınç uygulaması, aspirasyon uygulaması, Buzzy, müzik, ShotBlocker, ekstremitelerin internal rotasyonu gibi farklı farmakolojik ve non-farmakolojik yöntemler kullanıldığı sonucuna ulaşılmıştır. Kullanılan bu yöntemlerle uygulanan enjeksiyonlarda hastaların yaşadığı enjeksiyon ağrısı önemli ölçüde azaltılmıştır. Bireyin ağrısının dindirilmesi ve konforunun sağlanmasından sorumlu olan hemşirelerin güncel literatürü takip ederek, etkinliği saptanmış yöntem ve yaklaşımları hayata geçirmesi, uygulamalarını bilimsel bilgiye dayandırması ve literatüre kanıt oluşturabilecek veriler sunması açısından IM enjeksiyon uygulamasında non-farmakolojik yöntemlerin kullanılması oldukça önemlidir.

Gelișen ve değișen dünyada güncellenen bilgilerin klinik alana aktarılması ve bu amaca yönelik eğitimlerin sürekliliğinin sağlanması oldukça önemlidir (Bilgiç ve Şendir, 2014). Bu bağlamda lisansüstü tezler incelendiğinde İM enjeksiyon uygulamasına yönelik hemşirelere ve ebelere ventrogluteal bölgeye İM ilaç uygulama becerisinin geliştirilmesinde, öğrencilere IM enjeksiyona yönelik bilgi ve becerilerinin artırılması, öğrencilerin kaygı düzeylerinin azaltılması ve IM enjeksiyon becerisini kazandırmaya yönelik verilen planlı eğitimlerde; duygu, düşünce, dil ve davranışların etkin kullanımına odaklanan nöro linguistik programlama tekniği, hemşirelik eğitiminde video kullanımı ile öğrenme becerileri ve bilginin paylaşımı için bir strateji olarak kullanılan web destekli eğitimler, insan fizyolojisini belirli görevleri veya ortamları çeşitli yönleriyle modelleyen bilgisayar destekli eğitimler ve yardımcı araçlar ile birlikte standardize/simüle hasta yöntemi kombine olarak kullanılan hibrit simülasyon eğitimleri gibi çeşitli eğitim yöntem ve tekniklerini kullanıldığı saptanmıştır. Bu bağlamda amaca dönük bilimsel bilgi ve kanıta dayalı öğrenme hedefleri doğrultusunda nitelikli eğitim süreçlerinin mezuniyet sonrası klinik ortamlarda çalışan hemşirelerin nitelikli IM enjeksiyon uygulamaları gerçekleştirebilmesine büyük oranda katkı sağlayacağı düşünülmektedir. Yine ülkemizde klinik ortamlarda çalışan hemşirelere ve ebelere uygulama ortamlarında, öğrencilere eğitim öğretim ortamlarında verilen bu eğitimlerin büyük oranda başarılı olduğu ortaya konulmuştur. Türkiye'de yapılan çalışmalar kapsamında literatür incelendiğinde, Gülnar ve Özveren (2016) tarafından yapılan çalıșmada hemşirelere verilen eğitimin bilgi ve İM enjeksiyon uygulama becerileri üzerinde olumlu bir etkisi olduğu ve hemşirelerin farkındalıklarının arttığı bildirilmiştir. Şanlıalp ve Kurban (2017), tarafından hemşirelere $\mathrm{Z}$ tekniği ve ventrogluteal bölge ile ilgili verilen eğitimin etkinliğinin değerlendirildiği çalışmada eğitim sonrası bilgi puan ortalamasının eğitim öncesine göre anlamlı derecede yüksek olduğu tespit edilmiştir. Yine Vicdan ve arkadaşları (2019) hemşirelere hazırlanan eğitim kitapçı̆̆ doğrultusunda verilen eğitimin hemşirelerin bilgi düzeylerinde pozitif yönde anlamlı bir değişiklik sağladığını 
tespit etmiştir. Bu bağlamda İM enjeksiyon öğretiminde eğitim içeriği ve yöntemine ilişkin güncel kanitlar ve interaktif yöntemlerin kullanılması hayati bir öneme sahiptir.

\section{SONUC}

Temel bir hemşirelik işlevi ve hemşirelik araştırmalarının önemli ilgi alanlarından biri olan IM enjeksiyon uygulamalarına yönelik yapılan lisansüstü tezlerden elde edilen sonuçlara göre, IM enjeksiyon uygulamasını konu alan tezlerin sayıca yetersiz olduğu; konuya ilişkin akademik çalışmaların artması ile diğer araştırmalara ışık tutacağı, bu alanda yürütülen eğitimlerin çağdaş yöntem ve teknolojilere göre yapılandırılmasının kanıt temelli uygulamalar için de önemli bir bilgi girdisi sağlanacağı düşünülmektedir.

\section{Finansman kaynağı}

$\mathrm{Bu}$ çalışma sırasında, ne araştırma konusu ile doğrudan bağlantısı olan herhangi bir ilaç firmasından ne de bu çalışmanın değerlendirme sürecini olumsuz etkileyebilecek tıbbi alet ve malzemeleri sağlayan veya üreten bir firmadan maddi veya manevi destek alınmamıştır.

\section{Çıkar çatışması}

Yazarların herhangi bir çıkara dayalı ilişkisi bulunmamaktadır.

\section{KAYNAKLAR}

Ağaç E, Güneş ÜY (2011) Effect on pain of changing the needle prior to administering medicine intramuscularly: a randomized controlled trial, Journal of Advanced Nursing 67 (3): 563-568.

Akcimen M, Bedel C, Selvi F (2019) Application of ice and vapocoolant spray to reduce tetanus vaccine pain: A prospective, randomized, controlled clinical study. Annals of Medical Research 26 (6): 995-8.

Apaydın E (2018) Ventrogluteal ve dorsogluteal bölgeye uygulanan intramüsküler enjeksiyonların kanama, ağrı ve hematom açısından karşılaștırılması. Yüksek Lisans Tezi. Karadeniz Teknik Üniversitesi.

Ardahan M, Özsoy S (2015) Türkiye'de hemşirelik araştırmalarındaki eğilimler: yüksek lisans ve doktora tezleri üzerine bir çalışma. Gümüșhane Üniversitesi Sağlık Bilimleri Dergisi 4(4): 516-534.
Baran L (2020) Ventrogluteal bölgeden uygulanan intramüsküler enjeksiyonda aspirasyon işleminin gerekliliğinin ve ağrı üzerine etkisinin incelenmesi. Doktora Tezi. Ege Üniversitesi.

Berman A, Snyder S, Frandsen G (2016) Kozier and Erb'S Fundamentals of Nursing. Concepts, Process and Practice, 10th ed. New Jersey: Pearson Education Inc.

Bilgen Sivri B (2016) Çocuklarda intramüsküler enjeksiyon uygulanırken oluşan ağrıyı azaltmada iki farklı yöntemin etkisi. Doktora Tezi. İstanbul Üniversitesi.

Bilgiç Ş, Şendir M (2014) Hemşirelik bilişimi. Cumhuriyet Hemşirelik Dergisi 3(1): 24-28.

Cihangir Köktepe Ş (1998) İntramüsküler enjeksiyona bağlı ağrının azaltılmasında lokal buz uygulamasının etkinliğinin incelenmesi. Yüksek Lisans Tezi. Ege Üniversitesi.

Çelik Ş (2020) İntramüsküler penisilin enjeksiyonu uygulanacak bölgeye manuel basınç uygulamanın enjeksiyon ağrısı üzerine etkisi. Yüksek Lisans Tezi. Atatürk Üniversitesi.

Çöçelli LP, Bacaksız BD, Ovayolu N (2008) Ağrı tedavisinde hemşirenin rolü. Gaziantep Tıp Dergisi 14(2): 53-8.

Diş̧̧i R (2020) Hemşirelere verilen kanıta dayalı ventrogluteal bölge intramüsküler enjeksiyon eğitiminin etkinliği. Yüksek Lisans Tezi. Sağlık Bilimleri Üniversitesi.

Emre Yavuz D (2011a) İntramüsküler benzatin penisilin $g$ enjeksiyonunda manüel basınç uygulamanın enjeksiyon ağrısına etkisinin değerlendirilmesi. Yüksek Lisans Tezi. Marmara Üniversitesi.

Emre Yavuz D (2017b) Süt çocuğunun intramüsküler enjeksiyon ağrısına ilaç dışı multimodal yaklaşım. Doktora Tezi. Marmara Üniversitesi.

Eroğlu S (2016) Ventrogluteal alana intramüsküler enjeksiyon uygulamasına yönelik hemşirelere ve ebelere verilen eğitimde nöro linguistik programlama tekniğinin etkisi. Yüksek Lisans Tezi. Manisa Celal Bayar Üniversitesi.

Erol A (2017) Web destekli öğretimin hemşirelik öğrencilerinin intramüsküler enjeksiyonu öğrenmelerine etkisi. Yüksek Lisans Tezi. Ege Üniversitesi. 
Floyd S, Meyer A (2007) Intramuscular injections what"s best practice. Nursing New Zeland 13 (6): 2022.

Gökbel Yiğit K (2017) Hemşirelerin intramüsküler enjeksiyon uygulamasında ventrogluteal bölgenin kullanımına ilişkin verilen planlı eğitimin bilgi ve becerileri üzerine etkisi. Yüksek Lisans Tezi. Manisa Celal Bayar Üniversitesi.

Göktaş N (2014) Hemşirelerin intramüsküler ve intravenöz ilaç uygulamalarının değerlendirilmesi. Yüksek Lisans Tezi. Erciyes Üniversitesi.

Gülnar E (2012) Hemşirelerin intramüsküler enjeksiyonda ventrogluteal bölgenin kullanımına yönelik bilgi düzeylerinin belirlenmesi. Yüksek Lisans Tezi. Gazi Üniversitesi.

Gülnar E, Özveren H (2016) An Evaluation of the effectiveness of a planned training program for nurses on administering intramuscular injections into the ventrogluteal site. Nurse Education Today $36: 360-3$.

İşseven SD (2020) İntramüsküler enjeksiyon uygulama sonrası hastaların ağrı şiddeti ve memnuniyet düzeyleri açısından dorsogluteal ve ventrogluteal bölgelerinin karşılaştırılması. Yüksek Lisans Tezi. Manisa Celal Bayar Üniversitesi.

Kant E (2015) İntramüsküler enjeksiyon öncesi dinletilen müziğin ve bölgeye uygulanan basıncın ağrı üzerine etkisi. Yüksek Lisans Tezi. Erzurum Atattürk Üniversitesi.

\section{Kara D (2011) İntramüsküler enjeksiyon uygulamalarında ekstremitelerin internal rotasyonunun ve $\mathrm{z}$ yolu tekniğinin ağrı üzerine etkisinin incelenmesi. Yüksek Lisans Tezi. Ege Üniversitesi.}

Karabey T (2020) İntramüsküler enjeksiyonda ekstremitelerin internal rotasyonu, lokal soğuk uygulama ve shotblocker kullanımının enjeksiyon ağrısı ve konfor düzeyi üzerine etkisinin karşılaştırılması. Doktora Tezi. Sivas Cumhuriyet Üniversitesi.

Karaman D (2015) Using ventrogluteal site in intramuscular injections is a priority or an alternative?. International Journal of Caring Sciences 8(2): 507.

Kaya N (2012) Parenteral ilaç uygulamaları. içinde: hemşirelik esasları, Atabek Aștı T, Karadă̆ A, (Editörleri). 1. Baskı, İstanbul, Akademi Basın ve Yayıncılık, 762-794.

Kemaloğlu Y (2013) İntramüsküler enjeksiyon uygulamasında dorsogluteal ve ventrogluteal bölgelerin ağrı, kanama, hematom riski açısından karşılaştırılması. Yüksek Lisans Tezi. Haliç Üniversitesi.

Kılıç Arslan B (2018) Hemşirelerin ventrogluteal bölgeye intramüsküler ilaç uygulama becerilerinin geliștirilmesinde hibrit simülasyon yönteminin etkinliğinin değerlendirilmesi. Doktora Tezi. Sağlık Bilimleri Üniversitesi.

Koçyiğit A (1997) Çocuklarda intramüsküler enjeksiyonlardan önce lokal anestetik etkili krem emla uygulaması ile eğitim verilerek yapılan hazırlı̆̆ın ağrıyı azaltmadaki etkinliklerinin karşılaştırılması. Yüksek Lisans Tezi. Ege Üniversitesi.

Legrand G, Guiguet-Auclair C, Viennet H, Aumeran C, Reynaud D, Badrikian L, Debost-Legrand A (2019) Nurses' practices in the preparation and administration of intramuscular injections in mental health: A cross-sectional study. Journal of Clinical Nursing 28(17-18): 3310-3317.

Mitchell JR, Whitney FW (2001) The effect of injection speed on the perception of intramuscular injection pain: A clinical update. AAOHN Journal 49 (6); ProQuest Hospital Collection 286.

Mraz MAI, Thomas C, Rajcan L. (2018) Intramuscular injection CLIMAT pathway: a clinical practice guideline. British Journal of Nursing 27(13): 752-756.

Nicoll LH, Hesby A (2002) Intramuscular injection: an integrative research review and guideline for evidence-based practice Applied Nursing Research 15 (3): 149-162.

Özer Demir S (2019) Hemşirelerin intramüsküler enjeksiyona yönelik bilgi düzeylerinin ve bölge tercih nedenlerinin araștırılması. Yüksek Lisans Tezi. Kafkas Üniversitesi.

Potter PA, Perry AG, Stockert P, Hall M (2017) Fundamentals of Nursing, 9th ed.. St. Louis: Elsevier Inc.

Rodgern M., King L (2000) Drawing up and administering intramuscular injections: a review of the literature, Journal of Advanced Nursing 31 (3): 574-582.

Small S (2004) Preventing sciatic nevre injury from intramuscular injections: literature review, Journal of Advanced Nursing 47 (3): 287-296.

Şahin M (2013) İntramüsküler enjeksiyon uygulanan erişkin hastalarda buzzy $®$ uygulamasının ağrı ve enjeksiyon memnuniyetine etkisi. Yüksek Lisans Tezi. Ege Üniversitesi. 
Şanlıalp AZ, Kurban NK (2017) Hemşirelerin intramüsküler enjeksiyon bilgi ve uygulamalarına eğitimin etkisi: $\mathrm{z}$ tekniği ve ventrogluteal alan. Hemşirelikte Araştırma ve Geliştirme Dergisi 19(1):26-37.

Tok Aydın Ş (2019) İntramüsküler enjeksiyonu shotblocker ile uygulamanın ağrı şiddetine etkisi. Yüksek Lisans Tezi. Nevşehir Hacı Bektaş Veli Üniversitesi.

Tuğrul E, Denat Y. (2014) Hemşirelerin ventrogluteal alana enjeksiyon uygulamaya ilişkin bilgi, görüş ve uygulamaları. Dokuz Eylül Üniversitesi Hemşirelik Yüksekokulu Elektronik Dergisi 2014 7(4): 275-284.

Uslusoy EÇ, Duran ET, Korkmaz, M (2016) Güvenli enjeksiyon uygulamaları. Hacettepe Üniversitesi Hemşirelik Fakültesi Dergisi 3(2): 50-57.

Uzelli D (2011) Yenidoğana uygulanan intramüsküler enjeksiyonda sukroz solüsyonunun ağrı üzerine etkisinin incelenmesi. Yüksek Lisans Tezi. Ege Üniversitesi.

Vicdan AK, Birgili F, Baybuga MS (2019) Evaluation of the training given to the nurses on the injection application to the ventrogluteal site: a quasiexperimental study. International Journal of Caring Sciences 12(3):1467-1479.

Walsh L, Brophy K (2011) Staff nurses' sites of choice for administering intramuscular injections to adult patients in the acute care setting. Journal of Advanced Nursing 67(5): 1034-1040.

Yıldız T (2014) Çocuklarda İntramüsküler penisilin enjeksiyonu ağrısına lokal buz uygulamasının etkisi. Yüksek Lisans Tezi. Haliç Üniversitesi.

Yılmaz Coşkun E (2017) İntramüsküler ilaç uygulama becerisinin öğretiminde bilgisayar destekli ve hibrid simülasyon kullanımının etkinliği. Doktora Tezi. İstanbul Üniversitesi.

Zhuo P, Gao D, Xia Q, Ran D, Xia W (2019) Sciatic nerve injury in children after gluteal intramuscular injection: Case reports on medical malpractice. Medicine, Science and the Law 59(3): 139-142. https://doi.org/10.1177/0025802419851980. 